\title{
Cervical cancer screening and prevention: how aware is the Indian woman?
}

\author{
Trapti M. Saxena1, Aditi J. Upadhye², Jayshree J. Upadhye ${ }^{3 *}$
}

\begin{abstract}
${ }^{1}$ Department of Preventive and Social Medicine, Vedant Institute of Medical Sciences, Palghar, Maharashtra, India ${ }^{2}$ Department of Preventive and Social Medicine, PDMMC, Amravati, Maharashtra, India

${ }^{3}$ Department of Obstetrics and Gynecology, Narayan Medical College and Hospital, Jamuhar, Bihar, India
\end{abstract}

Received: 29 November 2018

Accepted: 05 December 2018

\section{*Correspondence:}

Dr. Jayshree J. Upadhye,

E-mail: jayshreeupadhye@gmail.com

Copyright: (C) the author(s), publisher and licensee Medip Academy. This is an open-access article distributed under the terms of the Creative Commons Attribution Non-Commercial License, which permits unrestricted non-commercial use, distribution, and reproduction in any medium, provided the original work is properly cited.

\begin{abstract}
Background: Carcinoma of the cervix is the second most common cancer in women worldwide. It is the commonest cancer among Indian women. Awareness regarding cervical cancer and its prevention is quite low amongst Indian women. The Pap test is a simple and cost-effective technique for early diagnosis of cervical cancer.

Methods: It was a cross sectional study conducted in the months of September and October 2018. We included 200 women between 30 and 60 years of age.

Results: In present study, out of 200 respondents, $160(80 \%)$ respondents got married after 21 years of age while 40 $(20 \%)$ respondents got married below 21 years of age. $148(74 \%)$ respondents had 2 children, 30 (15\%) respondents had one child while $22(11 \%)$ respondents had 3 children. $166(83 \%)$ had heard about cervical cancer, $24(12 \%)$ knew that cervical cancer can be cured if detected in early stage while only $10(5 \%)$ knew that it can be prevented. $54(27 \%)$ respondents knew that pap smear test should be done as screening test to detect cervical cancer in early stage while 22 $(11 \%)$ respondents knew about HPV vaccine as preventive measure.

Conclusions: In present study, though women have heard about cervical cancer, proper knowledge was very less. Also, awareness about HPV vaccine and Pap smear was less. There is need for proper information and facilities for pap smear and HPV vaccination.
\end{abstract}

Keywords: Cancer prevention, Cervical screening, Health education, HPV vaccine

\section{INTRODUCTION}

In India, cervical cancer is one the leading causes of mortality among women. It accounts for $23.3 \%$ cancer deaths. Cervical cancer is one of the most common cancers worldwide. ${ }^{1}$ More than three-fourth of these patients are diagnosed in advanced stages leading to poor prognosis. $^{2}$

The reasons for the high mortality from cervical cancer in sub-Saharan Africa include lack of awareness of cervical cancer among people, health-care providers and policymakers. Along with this, limited access to high- quality health-care services and cervical screening programmes; and lack of functional referral systems lead to advanced stage at diagnoses. ${ }^{3}$

Through screening and early detection, breast and cervical cancer mortality rates have dramatically reduced, and survival rates have improved. ${ }^{4}$

Even though public awareness of breast and cervical cancer has improved screening rates, many women still have disproportionately low screening rates. ${ }^{5}$ Early detection of cervical cancer is possible with various screening tests. 68-84\% women undergo Pap smear 
testing in developed countries as compared to India where it is $2.6 \%$ to $6.9 \%$ among women. ${ }^{6}$

Sexually transmitted infection with human papilloma virus (HPV) is the main cause of development of carcinoma of cervix. Incidence of HPV increases with multiple sexual partners and poor genital hygiene. HPV types 16 and 18 have been categorized as high-risk types for cervical cancer. ${ }^{7}$ Low public awareness and overall low health care seeking behaviour of women are key challenges for cervical cancer prevention (CCP) in developing countries. ${ }^{8}$

Pap smear is a preventive test. It aims not to detect cancer but to reveal any cell changes that indicate that cancer could develop, so that early action can be taken.9 Carcinoma breast and carcinoma cervix are leading causes for cancer deaths in India. Still, these get detected only in late stages. Preventive measures and early detection of disease will help to decrease the burden of these cancers. ${ }^{10}$ Vaccination of girls between 9 and 12 years will decrease this burden. The use of HPV Vaccine has been approved by the Drug Controller of India. ${ }^{10}$ The objective of the present study was to evaluate the knowledge about cervical cancer and various cervical cancer screening methods, to analyse awareness about preventive measures and to explore the sources of information.

\section{METHODS}

It was a cross sectional study conducted in the months of September and October 2018. We included 200 women between 30 and 60 years of age attending Gynecology OPD of a tertiary care hospital named Vedant Institute of Medical Sciences, Dahanu, Distt Palghar, Maharashtra, India. This institute is situated in rural area so females visiting this hospital are from nearby villages. So, data collected in this study is from rural India. In this study, information was collected about awareness of screening of cervical cancer and its prevention.

\section{Inclusion criteria}

- Women who were between 30 and 60 years of age.

- Women who have given consent for participation in the study.

\section{Exclusion criteria}

- Women who were below 30 or above 60 years of age.

- Women who did not give consent for participation in the study.

- The questionnaire was designed based on cervical cancer awareness. It was pretested on a sample of 30 women to check for feasibility and reliability and modified accordingly for use in the study.

- They were interviewed with the questionnaire after getting informed verbal consent from all participants.
Table 1: Questionnaire.

\begin{tabular}{|l|}
\hline Variables \\
\hline Name \\
\hline Age \\
\hline Do you know about cervical cancer? \\
\hline Is it preventable? \\
\hline Do you know about HPV vaccine? \\
\hline Do you know about Pap smear test? \\
\hline Is cervical cancer curable? \\
\hline
\end{tabular}

The responses was collected in Microsoft excel sheet. Data was analyzed. Descriptive statistics was taken out in percentages for categorical variables. After the collection of data, the women were informed about cervical cancer, the importance of its screening and facilities available for screening. Implications of positive and negative results of the screening were also explained. Information about $\mathrm{HPV}$ vaccine was also given. Importance of HPV vaccination specially to adolescent girls was explained.

\section{RESULTS}

In present study, out of 200 respondents, 96 (48\%) respondents were of $41-50$ years, 48 (24\%) respondents were of 51-60 years while $36(18 \%)$ respondents were of 31-40 years (Table 2).

Table 2: Age distribution.

\begin{tabular}{|l|l|l|}
\hline Age distribution & No. of females & Percentage \\
\hline 31-40 years & 36 & 18 \\
\hline $41-50$ years & 96 & 48 \\
\hline $51-60$ years & 48 & 24 \\
\hline
\end{tabular}

So, majority of population was in the age group of 41-50 years. In present study, out of 200 respondents, $80(40 \%)$ were graduates, $42(21 \%)$ were postgraduates, $32(16 \%)$ had their education till 12th standard, $20(10 \%)$ were illiterate, $20(10 \%)$ had their education till 10th standard while $6(3 \%)$ respondents had their education of primary level (Table 3).

Table 3: Education.

\begin{tabular}{|l|l|l|}
\hline Education & No. of respondents & Percentage \\
\hline Illiterate & 20 & 10 \\
\hline Primary & 6 & 3 \\
\hline High school & 20 & 10 \\
\hline $12^{\text {th }}$ std & 32 & 16 \\
\hline Graduation & 80 & 40 \\
\hline Post-graduation & 42 & 21 \\
\hline Total & 200 & 100 \\
\hline
\end{tabular}

So, majority of population was graduate inspite of being from rural area. In present study, source of information about cervical cancer in $62 \%$ was doctor. Source of information was friend in $30 \%$, media like 
$\mathrm{TV} /$ radio/newspaper in $5 \%$ and relative in $3 \%$ girls (Table 4).

Table 4: Source of information.

\begin{tabular}{|l|l|l|}
\hline Source of information & No. of girls & Percentage \\
\hline Doctor & 62 & 62 \\
\hline Friend & 30 & 30 \\
\hline TV/ Radio/ Newspaper & 5 & 5 \\
\hline Relative & 3 & 3 \\
\hline
\end{tabular}

So, majority of females got the information from doctor followed by friend. In present study, out of 200 respondents, $166(83 \%)$ had heard about cervical cancer, $24(12 \%)$ knew that cervical cancer can be cured if detected in early stage while only $10(5 \%)$ knew that it can be prevented (Table 5).

Table 5: Awareness of knowledge, prevention and cure of cervical cancer.

\begin{tabular}{|c|c|c|}
\hline $\begin{array}{l}\text { Awareness of knowledge, } \\
\text { prevention and cure of } \\
\text { cervical cancer }\end{array}$ & $\begin{array}{l}\text { No. of } \\
\text { females }\end{array}$ & Percentage \\
\hline Knowledge & 166 & 83 \\
\hline Prevention & 10 & 5 \\
\hline Cure & 24 & 12 \\
\hline
\end{tabular}

So, overall awareness about cervical cancer was good but not of prevention and cure. In present study, out of 200 respondents, $54(27 \%)$ respondents knew that pap smear test should be done as screening test to detect cervical cancer in early stage while $22(11 \%)$ respondents knew about HPV vaccine as preventive measure (Table 6).

Table 6: Awareness of cervical cancer screening and HPV vaccination.

\begin{tabular}{|c|c|c|}
\hline $\begin{array}{l}\text { A wareness of prevention of } \\
\text { cervical cancer }\end{array}$ & $\begin{array}{l}\text { No. of } \\
\text { females }\end{array}$ & Percentage \\
\hline Pap smear & 54 & $27 \%$ \\
\hline $\begin{array}{l}\text { HPV vaccination to } \\
\text { daughters }\end{array}$ & 22 & $11 \%$ \\
\hline
\end{tabular}

So, awareness about pap smear was low and about HPV vaccination very low.

\section{DISCUSSION}

In present study, out of 200 respondents, $96(48 \%)$ respondents were of 41-50 years, 48 (24\%) respondents were of 51-60 years while 36 (18\%) respondents were of 31-40 years (Table 2).

Aswathy $\mathrm{S}$ et al found that the mean age of women in the study population was $34.5 \pm 9.23$ year with the age range from 15-50 year. 14 A majority of the women (740, $91.4 \%)$ were non-working and most of them (651, $80.4 \%$ ) were homemakers. ${ }^{11}$ In present study, out of 200 respondents, $80(40 \%)$ were graduates, $42(21 \%)$ were postgraduates, $32(16 \%)$ had their education till 12th standard, $20(10 \%)$ were illiterate, $20(10 \%)$ had their education till 10th standard while $6(3 \%)$ respondents had their education of primary level (Table 3 ).

In present study, source of information about cervical cancer in $62 \%$ was doctor. Source of information was friend in $30 \%$, media like TV/radio/newspaper in 5\% and relative in $3 \%$ women (Table 4 ).

Aswathy $S$ et al found that the most common and important source of information mentioned was media $(452,55.8 \%)$ followed by health workers and doctors $(273,33.74 \%)$. Family and friends was cited by 119 $(14.7 \%)^{11}$

Harsha Kumar $\mathrm{HN}$ et al found that the source of information was mainly mass media. Majority of the women who had approached the doctors in the last 1 year $(89.3 \%$ [66/74]) and in the last 5 years $(80.7 \%$ [67/83]) were not told/educated about cervical cancer. ${ }^{12}$

In present study, out of 200 respondents, $166(83 \%)$ had heard about cervical cancer, 24 (12\%) knew that cervical cancer can be cured if detected in early stage while only $10(5 \%)$ knew that it can be prevented (Table 5).

Harsha Kumar HN et al found that majority of the women had poor knowledge about cervical cancer and its screening. 81.9\% [68/83] of the women were not aware of facilities for screening.

Lack of knowledge is reflected in poor understanding of symptoms. $^{12}$

Yanikkerem E et al found that among 1036 Turkey women $64.4 \%$ women had heard about cervical cancer, $43.1 \%$ had heard about pap test and only $24.7 \%$ had had a pap test at least once. Being uncomfortable with the procedure and not knowing where to go for Pap test were the common reasons not to undergo screening. ${ }^{13}$

In present study, out of 200 respondents, 54 (27\%) respondents knew that pap smear test should be done as screening test to detect cervical cancer in early stage while $22(11 \%)$ respondents knew about HPV vaccine as preventive measure. (Table 6)

Amos D et al found that $90 \%$ (444/448) had heard about cervical cancer. Of these, $70.3 \%$ reported that cervical cancer is preventable. $92 \%$ reported that cervical cancer can be cured, when diagnosed at an early stage.

There was limited awareness that cervical cancer can be prevented through Pap smears $(41 \%)$ or HPV vaccination of young girls $(8.3 \%)$. While about 1 in $3(30.5 \%)$ participants had heard about the role of a sexually transmitted virus the development of cervical cancer. ${ }^{14}$ Netsanet Shiferaw et al found that $75.3 \%$ women believed that cervical cancer is a preventable disease, 
$66.2 \%$ said that it can be cured. ${ }^{15}$ Asthana $\mathrm{S}$ et al found that $84.9 \%$ had knowledge of cancer in general and $72.3 \%$ had knowledge of cancer of the uterine cervix in particular. $96.1 \%$ of the women expressed willingness to visit a government health centre to undergo screening. $79.1 \%$ stated that their husbands would have no objection if they underwent screening. Overall, the community's awareness of cervical cancer was good and the response to the screening was positive. ${ }^{16}$

\section{CONCLUSION}

In present study, though women have heard about cervical cancer, proper knowledge was very less. Also, awareness about HPV vaccine and pap smear was less. There is need for proper information and facilities for pap smear and HPV vaccination.

\section{Funding: No funding sources}

Conflict of interest: None declared

Ethical approval: The study was approved by the Institutional Ethics Committee

\section{REFERENCES}

1. World Health Organization. Globocan fact sheets. International Cancer Research. Available at: http://www.globocan.iarc.fr/factsheet.asp\#WOMEN.

2. Guidelines for cervical cancer screening. Government of India and WHO Collaborative Program. Available http://www.whoindia.org/LinkFiles3.

3. WHO. Comprehensive Cervical Cancer Control; A Guide to Essential Practice. Geneva, Switzerland: WHO Press, World Health Organization, 2006.

4. Centers for Disease Control and Prevention. The National Breast and Cervical Cancer Early Detection Program 1991-2002 national report. Atlanta (GA): Department of Health and Human Services; 2005. Available at: http://www.cdc.gov/cancer/NBCCEDP/Reports/Nati onalReport/NBCCED_1991-

2002_National_Report.pdf

5. Hall HI, Uhler RJ, Coughlin SS, Miller DS. Breast and cervical cancer screening among Appalachian women. Cancer Epidemiol Biomarkers Prev 2002;11(1):137-42.

6. Swan J, Breen N, Coates RJ, Rimer BK, Lee NC. Progress in cancer screening practices in the United
States. Results from the 2000 national health interview survey. Cancer. 2003;97(6):1528-40.

7. International Agency for research on cancer IARC Monographs on Evaluation of Carcinogenic Risks to Humans. Human Papilloma Virus. 2007;90

8. Ntekim A. Cervical cancer in sub-Sahara Africa. InTopics on cervical cancer with an advocacy for prevention 2012. Intech.

9. Christian Nordqvist, What you need to know about cervical cancer, Medical News Today. 2017 Available

at: https://www.medicalnewstoday.com/articles/159821. php

10. Radha KR, Reena RP, Jacob KJ. Preventive gynecology: attitude and practice among gynecologists of Central Kerala. Int J Reproduct, Contracep, Obstet, Gynecol. 2017;6(6):2318-22.

11. Aswathy S, Quereshi MA, Kurian B, Leelamoni K. Cervical cancer screening: Current knowledge and practice among women in a rural population of Kerala, India. Indian J Med Res. 2012;136(2):205.

12. Kumar HH, Tanya S. A study on knowledge and screening for cervical cancer among women in Mangalore city. Ann Med Health Sci Res. 2014;4(5):751-6.

13. Yanikkerem E, Goker A, Piro N, Dikayak S, Koyuncu FM. Knowledge about cervical cancer, pap test and barriers towards cervical screening of women in Turkey. J Cancer Edu. 2013;28(2):375-83.

14. Mwaka AD, Orach CG, Were EM, Lyratzopoulos G, Wabinga H, Roland M. Awareness of cervical cancer risk factors and symptoms: cross-sectional community survey in post-conflict northern Uganda. Health Expect. 2016;19(4):854-67.

15. Shiferaw N, Brooks MI, Salvador-Davila G, Lonsako S, Kassahun K, Ansel J, et al. Knowledge and Awareness of Cervical Cancer among HIV-Infected Women in Ethiopia. Obstet Gynecol Int; 2016.

16. Asthana S, Satyanarayana L. Cervical cancer screening from the perspective of a rural population of northern India. Religion. 2013;61(19.4):11-9.

Cite this article as: Saxena TM, Upadhye AJ, Upadhye JJ. Cervical cancer screening and prevention: how aware is the Indian woman? Int J Reprod Contracept Obstet Gynecol 2019;8:59-62. 